\title{
In vitro Antimicrobial Activity of Honey and Lemon Juice Mixture against Clinical Isolates from Patients with Respiratory Tract Infections, Bamenda-Cameroon
}

\author{
Gerald Ngo Teke $^{1 *}$, Flore Nguemaïm Ngoufo $^{1}$, Alexis Njiki Njiki ${ }^{2}$ \\ and Henri Lucien Fouamno Kamga ${ }^{2}$
}

${ }^{1}$ Department of Biomedical Sciences, ${ }^{2}$ Department of Medical Laboratory Science, Faculty of Health Sciences, The University of Bamenda, P.O. BOX 39 Bambili, Cameroon

*Corresponding author

\begin{tabular}{|l|}
\hline K e y w o r d s \\
$\begin{array}{l}\text { Honey/lemon juice } \\
\text { mixtures, In vitro, } \\
\text { Antimicrobial } \\
\text { activity, Clinical } \\
\text { isolates, Bamenda- } \\
\text { Cameroon }\end{array}$ \\
\hline Article Info \\
\hline $\begin{array}{l}\text { Accepted: } \\
\text { 04 January } 2018 \\
\text { Available Online: } \\
\text { 10 February } 2019\end{array}$
\end{tabular}

\section{Introduction}

Honey is a sweet food made by bees using nectar from flowers. The variety produced by honey bees (the genus Apis) is the one most commonly referred to and is the type of honey collected by beekeepers and consumed by humans. There are many species including: Apis andreniformis, A. florea, A. dorsata, A. cerana, A. koschevnikovi, A. mellifera, A. 
nigrocincta (Denise et al., 2002). Most microorganisms do not grow in honey because of its low water activity of 0.6 (Molan, 1992). Hydrogen peroxide, methylglyoxal, bee defensin, $\mathrm{pH}$, osmotic effect as well as leptosin were known to be responsible for the antimicrobial effects of honey (Mandal, 2011; Kato et al., 2012).

Lemon fruit is an available citrus fruit, popular for its culinary and medicinal uses. Its fruit juice consists of about 5\% citric acid that gives to it a sour taste (NPCS, 2012). It is an important medicinal plant of the family Rutaceae. It is a rich source of vitamin $\mathrm{C}$ and it is cultivated mainly for its alkaloids, which are having anticancer activities and the antibacterial potential in crude extracts of different parts (viz., leaves, stem, root and flower) of lemon against clinically significant bacterial strains has been reported (Kawaii et al., 2000). Citrus flavonoids have a large spectrum of biological activity including antibacterial, antifungal, antidiabetic, anticancer and antiviral activities (Burt, 2004). There are different varieties of lemon including: Bush lemon tree, Eureka, Lisbon, Meyer, Ponderosa, and Variegated pink (NPCS, 2012). The species Citrus limon was used in this study. This study was aimed to determine the antibacterial activity of honey and lemon juice mixtures on strains of Staphylococcus aureus, Streptococcus pyogenes and yeast (Candida albicans) isolated and characterized by standard microbial procedures from respiratory tract of patients consulting at the Regional Hospital Bamenda.

\section{Materials and Methods}

\section{Collection of test materials and microbial samples}

Pure colonies of $S$. aureus, S. pyogenes and yeast ( $C$. albicans) isolated from throat and mouth was collected at the Microbiology Unit of the Regional Hospital Bamenda, Cameroon. Honey and ripen lemon fruits (Citrus limon) were purchased from the Bamenda food market. The honey was extracted from Mbengwi, a subdivision in the same Region of the North West of Cameroon.

\section{Verification of bacterial isolates from throat infections}

The microbial isolates from mouth and throat collected at the Microbiology Unit of the Regional Hospital Bamenda were sub-cultured on Blood agar and Sabouraud Dextrose agar for confirmation and were further subjected to Gram stain techniques, catalase test, coagulase test and lance field grouping (Cheesbrough, 2006). The bacterial and fungal strains were grown at $35^{\circ} \mathrm{C}$ and maintained on nutrient agar (NA, Conda, Madrid, Spain) and Sabouraud Dextrose Agar (SDA, Conda) respectively.

\section{Preparation of honey and lime mixture at various proportions}

The commercial honey obtained from Bamenda food market was kept in sterile screwed cap containers and stored at $5^{\circ} \mathrm{Cin}$ the Microbiology Laboratory of the Regional Hospital Bamenda prior to use.

Lemon fruits were obtained from the same market, washed with tap water and vinegar and then allowed to air dry. It was sterilized with 70\% alcohol and cut using a knife which was first sterilized with $70 \%$ alcohol and passed over flame. The lemon juice was squeezed, filtered using sterile cotton and glass funnel and placed in a sterile screwed cap container before refrigerating for later use.

The honey and lemon juice were remove from the fridge and the honey placed in warm water to bring it to the liquid state. Then both honey 
and lemon juice were allowed on the slap to attain room temperature. Using a $1000 \mu \mathrm{l}$ micropipette, the following five (5) mixtures were prepared at different proportions of each substance to a final volume of two milliliters (2 ml):

$90 \%$ (v/v) honey $+10 \%$ (v/v) lemon juice $(900$ $\mu \mathrm{l}$ honey+100 $\mu \mathrm{l}$ lemon juice)

$75 \%(\mathrm{v} / \mathrm{v})$ honey $+25 \%(\mathrm{v} / \mathrm{v})$ lemon juice (750 $\mu$ l honey $+250 \mu 1$ lemon juice)

$50 \%(\mathrm{v} / \mathrm{v})$ honey $+50 \%(\mathrm{v} / \mathrm{v})$ lemon juice $(500 \mu l$ honey $+500 \mu 1$ lemon juice $)$

$25 \%(\mathrm{v} / \mathrm{v})$ honey $+75 \%(\mathrm{v} / \mathrm{v})$ lemon juice $(250 \mu 1$ honey $+750 \mu 1$ lemon juice $)$

$10 \%(\mathrm{v} / \mathrm{v})$ honey $+90 \%(\mathrm{v} / \mathrm{v})$ lemon juice $(100$ $\mu \mathrm{l}$ honey $+900 \mu \mathrm{l}$ lemon juice)

\section{Preparation of antimicrobial discs from test mixtures}

Antimicrobial discs of $6 \mathrm{~mm}$ of diameter were made using Whattmann filter papern ${ }^{\circ} 3$. These discs were sterilized under ultraviolet light for $2 \mathrm{hrs}$ then submerged in the test mixtures for 30 minutes (Vineetha et al., 2015) such that each disc could absorb a quantity of about 20 $\mu l$ of prepared mixture.

\section{Preparation of microbial suspensions}

The microbial isolates were first activated by streaking on nutrient agar and incubating for 24 and 48 hours respectively for bacteria and yeast. A pipette with a sterile pipette tip was used to transfer $5 \mathrm{ml}$ of sterile saline distilled water into labeled sterile plain tubes. A wire loop was heat flamed, cooled and used to touch 3 to 5 well isolated similar colonies of the test organisms from the pure cultures and emulsified in the sterile saline distilled water in the labeled sterile plain tubes with each representing a particular isolate. Each microbial suspension in test tube was mixed vigorously, compared visually and adjusted to the turbidity standard of McFarland 0.5 (Cheesbrough, 2006).

\section{Antimicrobial susceptibility testing}

The various honey and lime fruit juice mixtures were tested for antimicrobial activities using agar disc diffusion technique to determine the diameter of growth inhibition zones.

\section{Agar disc diffusion test}

Briefly, a quantity of $100 \mu$ of suspension of the test microorganisms (prepared as mentioned above) was spread on Mueller Hinton agar and Sabouraud dextrose agar medium respectively for bacteria and yeast. Prepared filter paper discs such as to separately absorb $20 \mu \mathrm{l}$ of the different concentrations of honey/lemon fruity juice mixtures $(90 / 10,75 / 25,50 / 50,25 / 75$ and $10 / 90 \% \mathrm{v} / \mathrm{v}$ respectively) were placed on the seeded plates. This was done using sterile forceps under aseptic conditions. Ciprofloxacine (for bacteria) and ketoconazole (for yeast) were used as reference substances.

Within 30 minutes of applying the discs, the culture plates were inverted and incubated aerobically at $35^{\circ} \mathrm{C}$ for 24 hours for bacterial strains and 48 hours for yeast. This was done for each isolate and each assay in this experiment was repeated thrice. The diameters of zones showing complete microbial growth inhibition by gross visual inspection around each disc was measured in millimeters using a transparent meter rule over the back of the inverted plate and across each disc. A Clinical and Laboratory Standards Institute (CLSI) reference chart was used to report microbial sensitivity as follows: Resistant (0-8mm); Intermediate $(9-13 \mathrm{~mm})$; Sensitive $(14 \mathrm{~mm}$ and above).

\section{Determination of minimum inhibitory concentration (MIC) and minimum bactericidal concentration (MBC)}

The broth macrodilution technique was used for this assay (Barchiesi et al., 1994). This 
was done with the proportion of the mixture which with a majority of higher zones of microbial growth inhibition. I.e. 25\% honey: $75 \%$ (v/v) lemon fruit juice for Staphylococcus aureus and Streptococcus pyogenes; and 10/90\% (v/v) for Candida albicans using broth dilution method. These mixtures were prepared and considered mother test samples from which a certain quantity was obtained (x ml) and transferred separately into $5 \mathrm{ml}$ test tubes previously containing Mueller Hinton broth or Sabouraud dextrose broth (y ml).

Freshly prepared microbial suspension $(20 \mu \mathrm{l})$ was then separately added to the tubes making a final volume of $3 \mathrm{ml}$ and the test concentrations were: $0,20,40,60,80$ and $100 \%$. A sterility control tube containing the test mixture and broth medium but no microorganisms was equally made. The tubes were vortexed and incubated at $35^{\circ} \mathrm{C}$ for 24 hours for bacterial strains and 48 hours for yeast. The turbidity of each test tube was visually inspected and compared with the control (tube with $0 \%$ test mixture). The lowest of the honey/lemon fruit juice mixture test concentration in clear test tubes was considered as the MIC (Keizo et al., 2012).

For the MBC determination, all the clear test tubes indicating no visible sign of microbial growth or turbidity in the MIC assay, were further sub-cultured on sterile Mueller Hinton agar/Sabouraud Dextrose agar plates by streak plate method.

Then the plates were incubated at $35^{\circ} \mathrm{C}$ for 24 hours for bacterial strains and 48 hours for yeast. The least concentration that did not show growth of test organisms was considered as the MBC.

\section{Data management and analysis}

Data on inhibition zone diameters were analysed using statistical package for social sciences (SPSS), version 20. Student Newman-Keuls test was used to compare inhibition diameters at different test concentrations. MICs and MBCs were expressed as \% of honey/lemon fruit juice mixtures.

\section{Ethical considerations}

Ethical clearance was obtained from the Institutional Review Board of The University of Bamenda (2018/0022/UBa/IRB). Administrative authorization was obtained from the Regional Hospital Bamenda.

\section{Results}

\section{Agar disc diffusion assay}

A total of four mixtures at different proportions of honey and lemon fruit juice were tested against microbial isolates causing throat infections: Staphylococcus aureus, Streptococcus pyogenes and Candida albicans. Globally, the diameter of microbial growth inhibition zones increased with decreasing proportion of honey in the mixtures. S. aureus was most sensitive to the mixture of $25 / 75 \%(\mathrm{v} / \mathrm{v})$ honey/lemon fruit juice producing a growth inhibitory diameter of $14 \mathrm{~mm}$ (Fig. 1).

Two proportions (75/25 and 90/10\% (v/v) of honey/lemon fruit juice mixtures were not able to inhibit the growth of $S$. aureus. This similar situation was observed for S. pyogenes (Fig. 2) in the presence of the test mixtures.

The honey and lemon fruit juice mixtures tested on Candida albicans isolate was active only at two test concentrations. The smaller diameter of growth inhibition zone was 8.66 $\mathrm{mm}$ at $25 \%(\mathrm{v} / \mathrm{v})$ honey $+75 \%(\mathrm{v} / \mathrm{v})$ lemon juice while the least honey content $(10 \%)$ in the mixture gave $11.33 \mathrm{~mm}$ inhibition zone diameter (Fig. 3). 
Table.1 Microbial susceptibility, MICs and MBCs of honey and lemon fruit juice mixtures

\begin{tabular}{|l|c|c|c|c|}
\hline \multicolumn{1}{|c|}{$\begin{array}{c}\text { Microbial } \\
\text { isolates }\end{array}$} & $\begin{array}{c}\text { Mean diameter }^{\mathbf{a}} \\
\text { value } \mathbf{\text { SD }}\end{array}$ & Susceptibility $^{\mathbf{b}}$ & \multicolumn{2}{|c|}{$\begin{array}{c}\text { Honey-lemon fruit } \\
\text { juice mixture }\end{array}$} \\
\cline { 3 - 5 } & & & MIC (\%) & MBC (\%) \\
\hline S. aureus & $17.33 \pm 0.28$ & Sensitive & 60 & $>80$ \\
\hline S.pyogenes & $13.33 \pm 0.57$ & Intermediate & 60 & $>80$ \\
\hline C. albicans & $9.99 \pm 0.57$ & Intermediate & 80 & $>80$ \\
\hline
\end{tabular}

${ }^{a}$ two test concentrations with high inhibition zones were considered; ${ }^{b}$ Resistant $(0-8 \mathrm{~mm})$; Intermediate $(9-13$ $\mathrm{mm}$ ); Sensitive (14 $\mathrm{mm}$ and above); SD: standard deviation

Fig.1 Staphylococcus aureus growth inhibition at various proportions of honey/lemon fruit juice mixtures

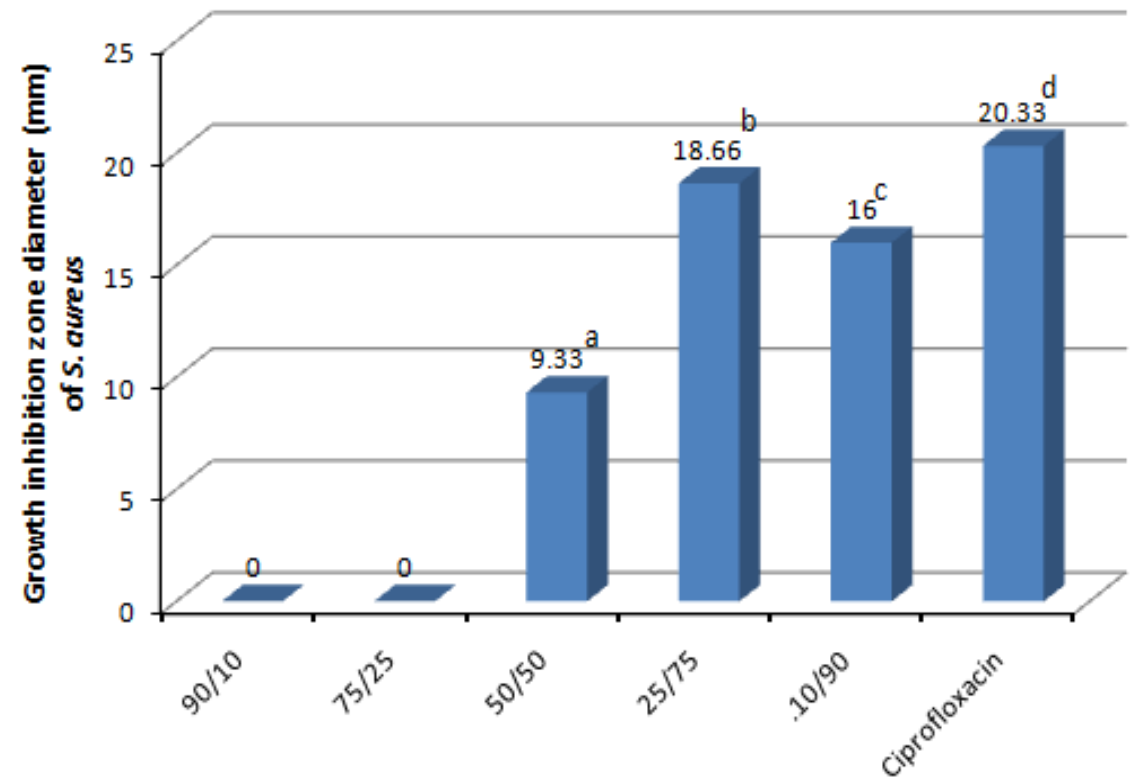

Concentration of test samples (\%)*

${ }^{a}$ Values with different superscripts are significantly different; Student Newman Keuls at $p<0.05$.

*The proportion of honey decreases while that of lemon fruit juice increases 
Fig.2 Streptococcus pyogenes growth inhibition at various proportions of honey/lemon fruit juice mixtures

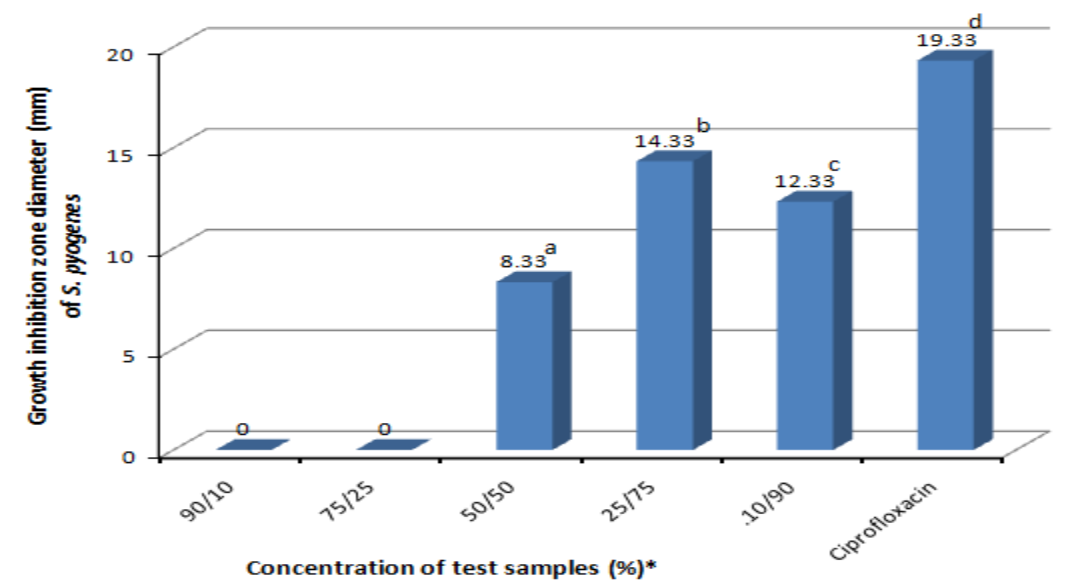

${ }^{a}$ Values with different superscripts are significantly different; Student Newman Keuls at $p<0.05$.

*The proportion of honey decreases while that of lemon fruit juice increases

Fig.3 Candida albicans growth inhibition at various proportions of honey/lemon fruit juice mixtures

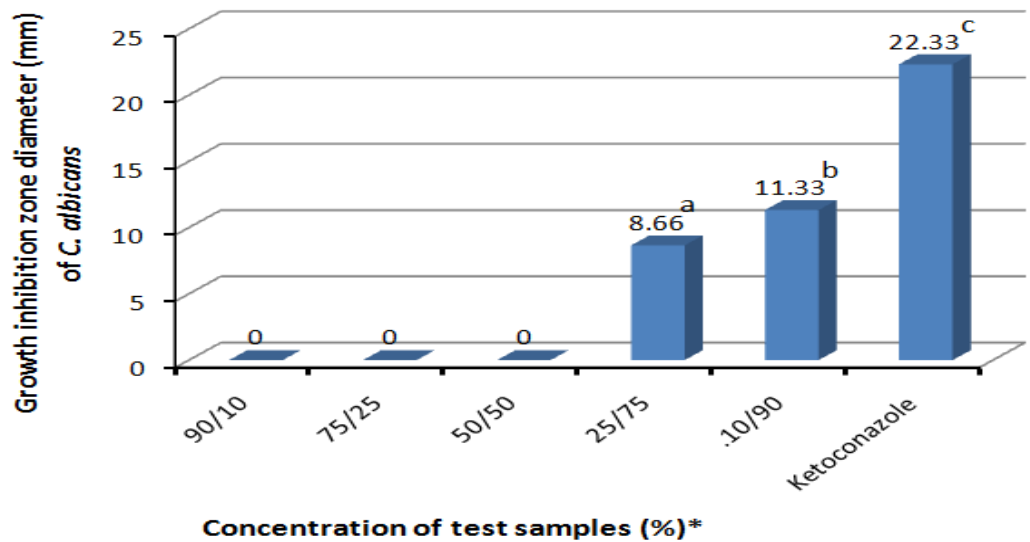

${ }^{a}$ Values with different superscripts are significantly different; Student Newman Keuls at $p<0.05$.

*The proportion of honey decreases while that of lemon fruit juice increases

Minimum inhibitory concentration (MIC) and minimum bactericidal concentration (MBC)

Only one proportion of the mixtures with larger zones of growth inhibition on bacteria/ yeast was used to determine the MIC and MBC. The MIC values for $S$. aureus and $S$. pyogene were recorded as $60 \%$ concentration of test mixture (Table 1). C. albicans had a higher MIC value (80\%). All the MBC values for the test microorganisms were considered greater than $80 \%$ of test mixtures.

In a study, bacteria and yeast isolated from patients presented with respiratory infections were tested for susceptibility in the presence of honey/lemon juice mixtures. The honey/lemon juice mixtures were more active in inhibiting bacterial growth at higher lime proportions. Moderate microbial susceptibility was observed at $50 \%$ mixture 
concentration. This finding is similar to that reported by Mshelia et al., (2017) in the susceptibility of similar microbes to this mixture.

In our study, the microbial inhibition zones for the mixture at 50:50 were slightly lower (less than $20 \mathrm{~mm}$ ) compared to their findings (greater than 20mm). Considering the effects of honey and lemon juice mixtures at appropriate concentrations, the observed antimicrobial potential was slightly higher compared to those of honey and lemon juice tested singly as reported elsewhere (Mshelia et al., 2017). It is worth mentioning that the microbial specimen and test materials may respond with slight differences regarding their sources and environmental conditions as suggested by Allison and Jennifer (2008).

From our findings, $C$. albican exposed to the honey/lemon juice mixtures was susceptible only at low honey but high lemon juice proportions $\quad(25 / 75 \%$ and $10 / 90 \%$ respectively). Moreover, the highest test concentration (80\%) could not kill the fungal agent. Similar studies with honey showed that it had antifungal activity against $C$. albicans (Shayeste et al., 2013; Somnath et al., 2017; Koc et al., 2008) showed that honey/lemon juice mixture was efficient in inhibiting the growth of some fungal agents including $C$. albicans.

Other researchers have reported that honey inhibited the growth of Candida even up to $100 \%$ concentration (AL-Waili et al., 2005). This fungal growth inhibition was not observed to be fungicidal as had equally been mentioned in other studies (Mayer and Williams, 2004; Bogdanov et al., 2008).

Many phytochemical compounds with antibacterial components have been reported separately in honey and lime juice. According to Sohn et al., (2004) and Soetan et al.,
(2006), some components like phenolic, flavonoids, alkaloids, saponins, tannins, steroids, glycosides and triterpenoids in lemon juice have antibacterial activity against gram positive and negative bacteria. In addition, some of these components like phenols may interfere with the active transportation of substances across the cytoplasmic membrane (Davidson and Naidu, 2000), thereby provoking bacterial death.

Honey has been reported to be acidic (Teke and Betie, 2016; Ball, 2007) and rich in hydrogen peroxide (produced by glucose oxidase originating from the bees) and methylglyoxal (Ramalivhana et al., 2014; Mavric et al., 2008; Paulus et al., 2008). Lemon juice is equally known to be acidic (Kwakman et al., 2008). Hence the acid nature of the mixture and the presence of hydrogen peroxide could be contributory factors to bacterial growth inhibition (Manisha and Shyamapada, 2011; Amal, 2014) beside other antimicrobial properties they are known to possess.

The results of our study showed that appropriate mixtures of honey and lemon juice (lemon $50-75 \%$ for bacteria and $75-90 \%$ for yeast) exhibit antibacterial and antifungal activities.

Inadequate anti-infective treatment mostly due to financial hardship is a contributing factor among others to the emergence of microbial resistance. Hence the use of honey and lemon, which can easily be obtained, and whose efficacy has been proven could be a better alternative treatment against some infectious diseases.

\section{Acknowledgements}

We are grateful to the Microbiology Laboratory staff of the Regional Hospital Bamenda for their technical assistance. 


\section{References}

Allison, S.D., Jennifer, B.H.M. 2008. Resistance, resilience, and redundancy in microbial communities. PNAS. 105(suppl. 1): 11512-11519.

AL-Waili, N.S., Akmal, M., AL-Waili, F.S., Saloom, K.Y., Ali, A. 2005. The antimicrobial potential of honey from United Arab Emirates on some microbial isolates. Med Sci Monit.11: 433-438.

Amal, S.O. 2014. Antibacterial Activity of Bee and Yemeni Sidr Honey Against Some Pathogenic Bacterial Species. Int. J. Curr. Microbiol. App. Sci., 3(10): 10151025.

Ball, D. 2007. The chemical composition of honey. J. Chem. Educ., 84: 1643-1646.

Barchiesi, F., Arnaldo, L.C., Deanna, A.M., Michael, G.R. 1994. Comparative Study of Broth Macrodilution and Microdilution. Techniques for In Vitro Antifungal Susceptibility Testing of Yeasts by Using the National Committee for Clinical Laboratory Standards' Proposed Standard. Journal of Clinical Microbiology, 32(10): 24942500

Bogdanov, S., Jurendic, T., Sieber, R., Gallmann, P. 2008. Honey for nutrition and health: A review. J Am CollNutr. 27:677-689.

Burt, S.A. 2004. "Essential oils: Their antibacterial properties and potential applications in foods: A review". International Journal of Food Microbiology, 94(3): 223-253.

Cheesbrough, M. 2006. District Laboratory Practice in Tropical Countries (2nd edn). Cambridge University Press, New York; 178-194.

Davidson, P.M., Naidu, A.S. 2000. Phytophenols. In A. S. Naidu (Ed.), Natural food

antimicrobial systems. Boca Raton, FL: CRC Press; pp. 265-294.

Denise, M., Dubet, Silva M., Paulo, N.N. 2002.
"A High Grassland Bee Community in Southern Brazil: Survey and Annotated checklist (Insecta: Apidae)". Journal of Kansas Entomological Society, 85(4): 295-308.

Kato, Y., Natsuki, U., Asuna, M., Daiki, M., Noritoshi, K., et al., 2012. "Identification of a novel glycoside, leptosin, as a chemical marker of manuka honey". Journal of Agricultural and Food Chemistry, 60(12): 3418-23.

Kawaii, S., Satoru, K., Yasuhiko, T., Eriko, K., Kazunori, O., Masamichi, Yano., et al., 2000. "Quantitative study of flavonoids in leaves of Citrus plants". Journal of Agricultural and Food Chemistry, 48(9): 3865-3871.

Keizo, Y., Yoichi, H., Intetsu, K., Masanari, I., Akira, O. 2012.A report from the committee on microbroth dilution antimicrobial susceptibility testing Issues in antimicrobial susceptibility testing of Haemophilus influenza: a comparison of the Japanese Society of Chemotherapy lysed horse blood and the CLSI HTM broth microdilution methods. J Infect Chemother. 18:134143.

Koc, A.N., Silici, S., Ercal, B.D., Kasap, F., Hörmet-Öz, H.T., Mavus-Buldu, H. 2008. Antifungal activity of Turkish honey against Candida spp. and Trichosporonspp: An in vitro evaluation. Med Mycol. 47:707-12.

Kwakman, P.H., Van den Akker, J.P., Güçlü, A., Aslami, H., Binnekade, J.M. 2008. Medical-grade honey kills antibiotic resistant bacteria in vitro and eradicates skin colonization. Clin Infect Dis. 46 (11): 1677-16682.

Mandal, S. 2011. "Honey: its medicinal property and antibacterial activity". Asian Pacific Journal of Tropical Biomedicine, 1(2): 154-160.

Manisha, D.M., Shyamapada, M. 2011. Honey: its medicinal property and antibacterial activity. Asian Pacif. J. Trop. Biomed. 1(2): 154-160.

Mavric, E., Wittmann, S., Barth, G., Henle, T. 
2008. Identification and quantification of methylglyoxal as the dominant antibacterial constituent of manuka (Leptospermum scoparium) honeys from New Zealand. Molecular Nutrition and Foods Research, 52:483-489.

Mayer, B.H., Williams, L. 2004. Women's health: A guide to health promotion and disorder management. Lippincott Williams and Wilkins; Philadelphia; p. 405.

Molan, P.C. 1992. "The Antibacterial Activity of Honey-2. Variation in potency of the antibacterial activity". Bee World, 73: 59-76.

Mshelia, B.M., Adeshina, G.O., Onaolapo, J.A. 2017. The Antibacterial Activity of Honey and Lemon Juice against Streptococcus pneumonia and Streptococcus pyogenes Isolates from Respiratory Tract Infections. Adv Biotech \& Micro. 4(5): 001-008.

NPCS. 2012. "Handbook on Agro Based Industries (2nd Edition)". Published by Niir Project Consultancy Services, Delhi (India), 75-78.

Paulus, H.S., Kwakman, Johannes, P.C., Van den,A., Ahmet, G., Hamid, A., Jan, M.B., Leonie, B., Boszhard, L., Paulus, F., Middelhoek,P., Velde, A.A., Vandenbroucke-Grauls, C.M.J.E., Schultz, M.J., Zaat, S.A.J. 2008. Medical-grade honey kills antibiotic resistant bacteria in vitro and eradicates skin colonization. Clinical Infectious Diseases, 46: 1677-82.

Ramalivhana JN, Obi CL, Samie A, Iweriebor BC, Uaboi-Egbenni P, Idiaghe JE, Momba MNB. 2014. Antibacterial activity of honey and medicinal plant extracts against Gram negative microorganisms. Afr. J. Biotechnol.,
13(4): 616-625.

Shayeste, B.B., Gholam, R.M., Batoul, P., Majid, V. 2013. Comparison of the effect of honey and miconazole against Candida albicans in vitro. Adv Biomed Res. 2: 57.

Soetan, K.O., Oyekunle, M.A., Aiyelaagbe, O.O., Fafunso, M.A. 2006. Evaluation of the antimicrobial activity of saponins extract of Sorghum Bicolor L. moench. African Journal of Biotechnology, 5(23): 2405-2407.

Sohn, H.Y., Son, K.H., Kwon, C.S., Kwon, G.S., et al., 2004. Antimicrobial and cytotoxic activity of 18 prenylated flavonoids isolated from medicinal plants: Morusalba L., Morus mongolica Schneider, Broussnetia papyrifera (L.) Vent, Sophora flavescens Ait and Echinosophora koreensis Nakai. Phytomedicine, 11(7-8), 666-672.

Somnath, D., Nilanjana, M., Susmita, B., Puja, G., Snighadha, M., Moumi, D., Siddhartha, C. 2017. Investigate the Antimicrobial Activity of Raw Lemon and Honey against Human Enteric Pathogens in vitro. International Journal of Ayurvedic and Herbal Medicine, 7(1): 2469 -2474.

Teke, G.N., Betie, E.N. 2016. Antibacterial activity of three Cameroonian honey types against some pathogenic species. Int. J. Biol. Chem. Sci. 10(6): $2477-$ 2484.

Vineetha, N., Vignesh, RA., Sridhar, D. 2015. Preparation, Standardization of Antibiotic Disc and Study of Resistance Pattern for First-line Antibiotics in isolates from clinical samples. International journal of applied research, 1(11): 624-631.

\section{How to cite this article:}

Gerald Ngo Teke, Flore Nguemaïm Ngoufo, Alexis Njiki Njiki and Henri Lucien Fouamno Kamga. 2019. In vitro Antimicrobial Activity of Honey and Lemon Juice Mixture against Clinical Isolates from Patients with Respiratory Tract Infections, Bamenda-Cameroon. Int.J.Curr.Microbiol.App.Sci. 8(02): 35-43. doi: https://doi.org/10.20546/ijcmas.2019.802.007 